
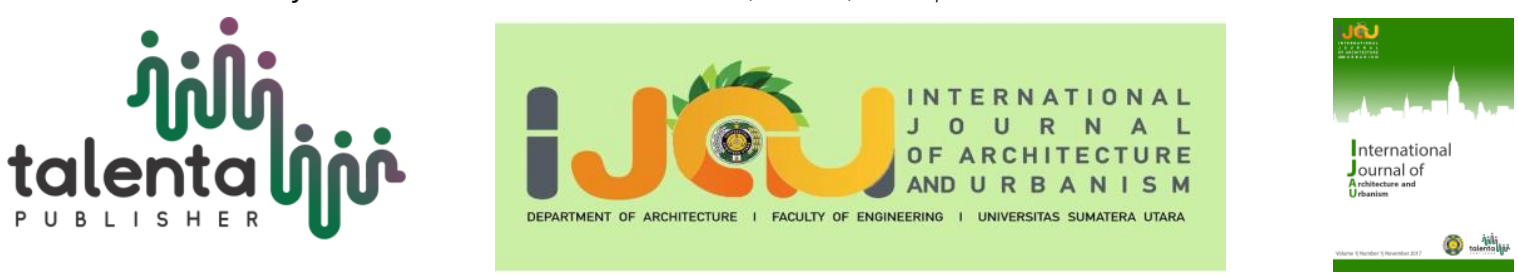

\title{
Ulos Weaving Center (Neo Vernacular Architecture)
}

\author{
Atifah $N$ Tarigan $^{I^{*}}$, Morida Siagian ${ }^{1}$ \\ ${ }^{I}$ Department of Architecture, Faculty of Engineering, Universitas Sumatera Utara, Medan, Indonesia
}

\begin{abstract}
Ulos is a well known cultural heritage, but as technology advances, the production of traditionally weaved Ulos began to be left behind, when in fact, the traditionally weaved Ulos held a very high artistic value and in need of preservation. Tarutung is an area with the potential to be developed as a tourist city with a variety of nature and culture, such as the Ulos craft, which is a valuable asset. Every year the Festival Tenun Nusantara is held in Tarutung that can support the design of the Ulos weaving center. That is why an Ulos center is needed. The methodology of this Ulos weaving center starts by conducting site selection, identifying problems and potential that exist on the site, then collecting data that support the design by searching ideas, literature studies related to titles and themes, observation studies, and comparative studies. The Ulos weaving center uses the neo vernacular architecture theme by incorporating local wisdom and natural surroundings of the site, a rice field that becomes an innovative attraction. Therefore, Ulos weaving center allows people to get to know Ulos deeply in a whole new experience and a place suitable to enrich and conserve cultural tradition in Tarutung.
\end{abstract}

Keyword: culture, neo-vernacular, tarutung, tourism, ulos

Received date month year. | Revised 17 October 2020 | Accepted 29 November 2020

\section{Introduction}

Tourism is one of the most important economic sectors in Indonesia because tourism in Indonesia is among the fastest-growing sectors. Tourism is a type of industry that can quickly boost the economy and make new employment and stimulate other sectors [1]. With this much potential, tourism development must be made and planned carefully. One of them, by including local elements. Besides reinforcing the concept of tourism, it will also elevate the local wisdom of the area, because this identity will attract people to come and visit. Thus, in the effort to develop tourism, there is community involvement and participation related to economic improvement, introducing the creative industries of surrounding communities, and introducing tradition and local architecture. This involvement will make the local people have a sense of

\footnotetext{
${ }^{*}$ Corresponding author at: Department of Architecture, Faculty of Engineering, Universitas Sumatera Utara, J1. Perpustakaan Gedung J07, Medan 20155, Indonesia

E-mail address: atifahnureza@gmail.com
} 
belonging, and this is inseparable from the uniqueness and diversity of types of tourism in Indonesia.

One of the cultural heritages is traditional textiles. Through traditional textiles, we can not only see the treasure of cultural heritage, such as the production techniques, diverse patterns, and types of textiles. We can also recognize the various textile and the meaning of textile in the lives of people who reflect the tradition, agriculture, and cultural habits. Ulos has a sacred value for the Batak people [2].

Tarutung is an area that can be developed as a tourist city with a variety of natural beauty and rich culture that can be a valuable asset. Judging from the cultural potential possessed, Tarutung has enough potential to be developed as a tourist destination. Moreover, the Festival Tenun Nusantara that was initiated by the collaboration between the Government of North Tapanuli Regency and the Director-General of Culture, Ministry of Education and Culture (Kemendikbud) becomes a celebration of the Ulos Weaving tradition in the Batak land annually.

Based on the explanation above, an idea arises regarding the design of a cultural tourism site with Ulos as the basis for the design. It is a recreational place that can accommodate the creativity of the local community and value art. It is also a place for tourists to learn the process of weaving Ulos with a cultural tourism approach. Tourism development introduces tourists with local culture and development that involves empowerment and development by maintaining local wisdom and raising the people's socio-economic level in Tarutung.

\section{Literature Review}

Neo Vernacular Architecture

Neo-vernacular architecture is an application of existing architecture, physical (form, construction) and non-physical (concept, philosophy, spatial) to preserve local features. It can be used to help find a more modern work without ignoring the value of the tradition [3].

In Tarutung, Batak Toba culture is still very much attached, and there are still many traditional houses found and some modern buildings that formed from a traditional house [4]. Batak Toba's traditional house stands on stilts and has a pitched roof [5] (Figure 1). 


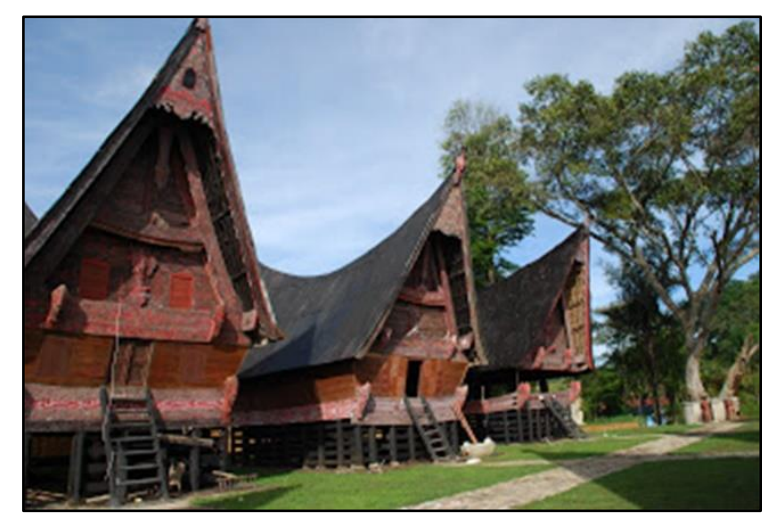

Figure 1 Batak Toba traditional houses

The theme applied to Ulos Samosir Weaving Center is Neo Vernacular architecture. With this approach, the project is expected to reflect locality but with a new, modern design while still applying the local values [6].

Ulos

Ulos is a Batak woven cloth. Ulos is considered a sacred object by Batak people, whose interpretation of this object is a symbol of blessing, affection, and unity. By following the Batak saying that reads: Ijuk pangihot ni hodong, Ulos pangihot ni holong, which means if ijuk is a binder on the stem, then Ulos is a binder of affection between people [7]. There are many types of Ulos, although different patterns or patterns (ragi) (Figure 2).

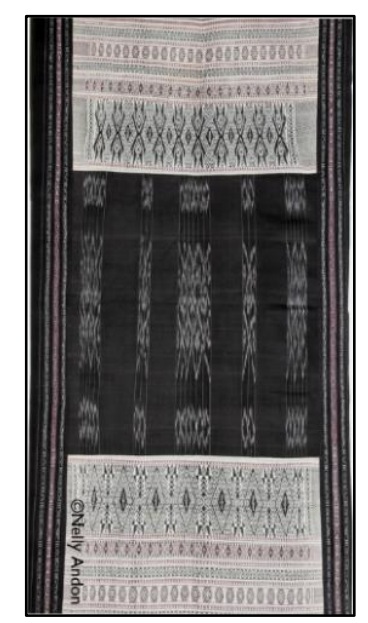

Figure 2 Ulos Ragi Idup

Ulos have spiritual values. Giving Ulos is always defined as the excitement of life, happiness, far from danger, getting blessings, and offspring. Ulos is the delivery of prayers and hopes that those who receive Ulos get a blessing from God [8]. 


\section{Methodology}

For site selection, site observations were carried out, including access to the site, natural potential, land use, location orientation, location view, location topography, and site feasibility. The first step of the observation method is to conduct a field survey, collecting data, identifying problems, and potential that exists on the site. Data is tangible as notes, schematic drawings, and media files (photos and videos). Then the literature data method is done by collecting data from literature books and scientific journals. This method's result is primary and secondary data, which used as material for analysis that will support design theory [9].

\section{Result and Discussion}

The project location is in Tarutung, North Tapanuli (Figure 3). The location is considered potential because it is close to the city and not far from several tourist destinations around Tarutung. The original function of this site is paddy fields.

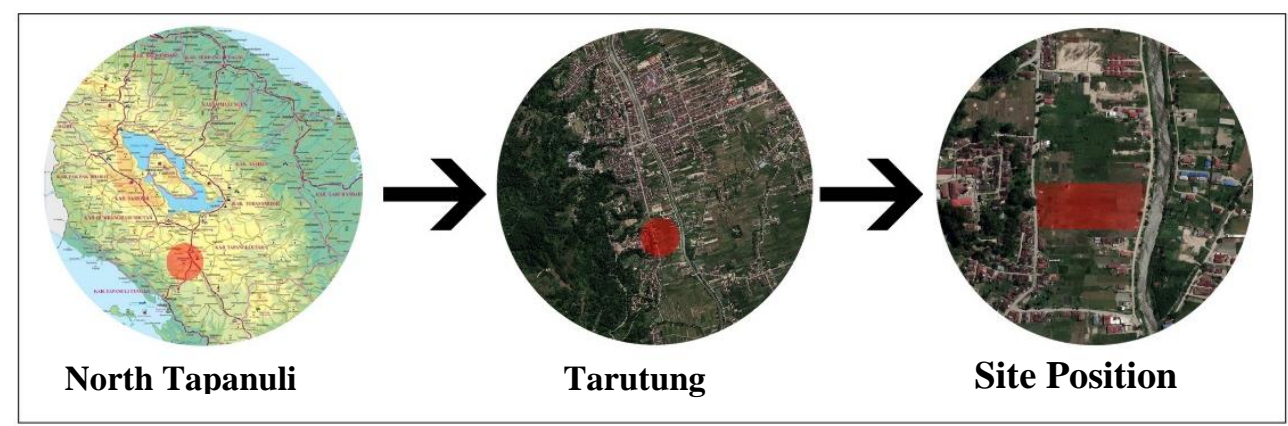

Figure 3 Site position

\section{Concept}

The main concept of the Ulos Weaving Center in Tarutung is to combine nature and culture. Paddy fields are maintained, which can be a selling point for the design. integrating paddy field activities and weaving Ulos gives visitors a different experience and a peaceful atmosphere like in the countryside (Figure 4).

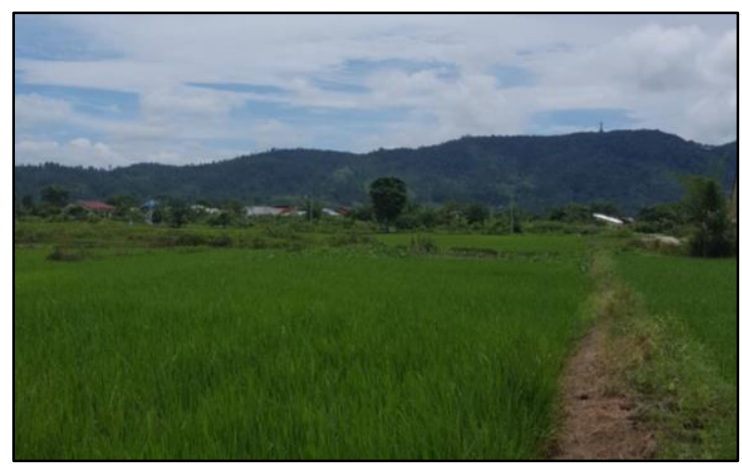

Figure 4 Site situation 
The building is made open as much as possible to unite the inner and outer space. The following three concepts are applied to the design (Figure 5).

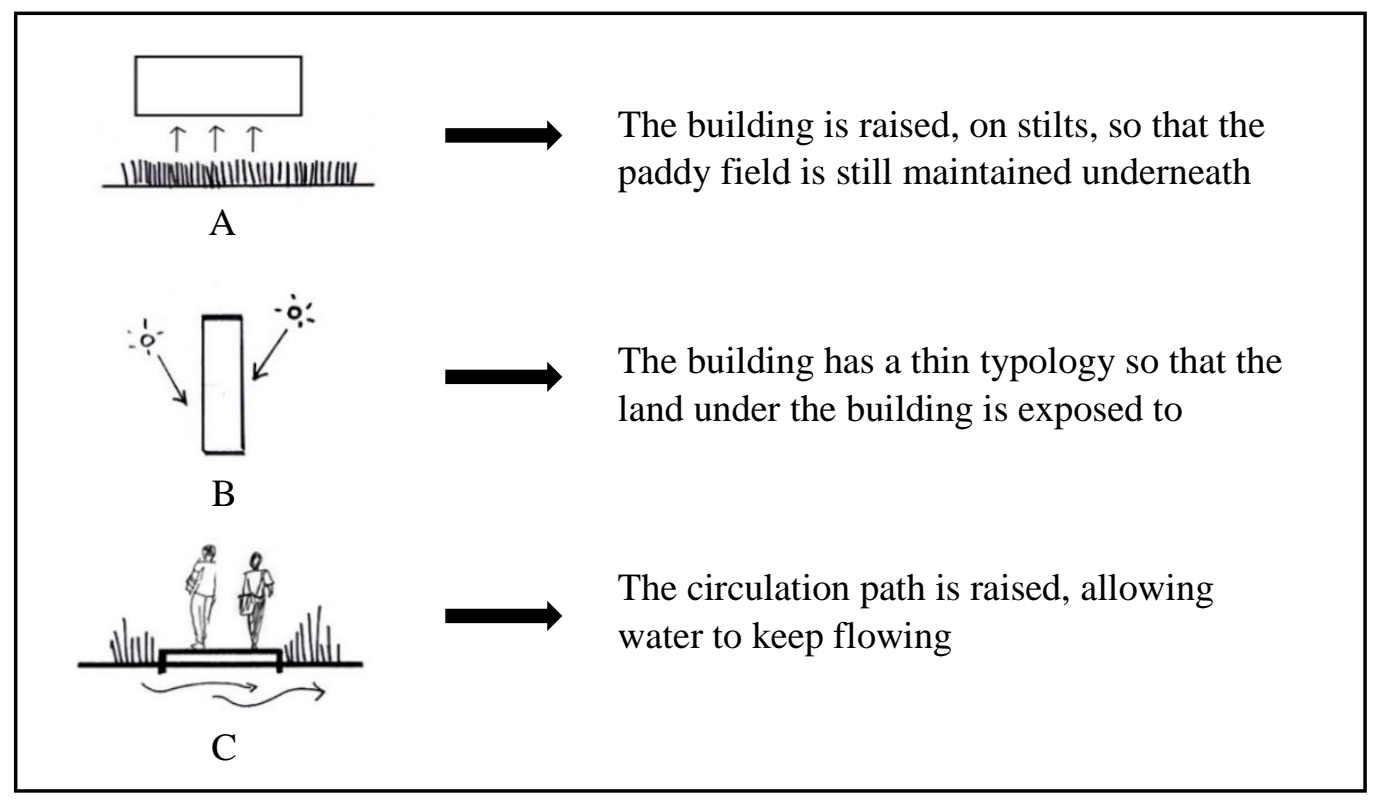

Figure 5 Concept

The building mass took inspiration from the form of Ulos Ragi Idup, which consists of three parts, two main parts connected by lines, applied to the design as two main mass and connected by a connecting road. Then the Ulos pattern repetition pattern is applied to the mass formation (Figure 6).

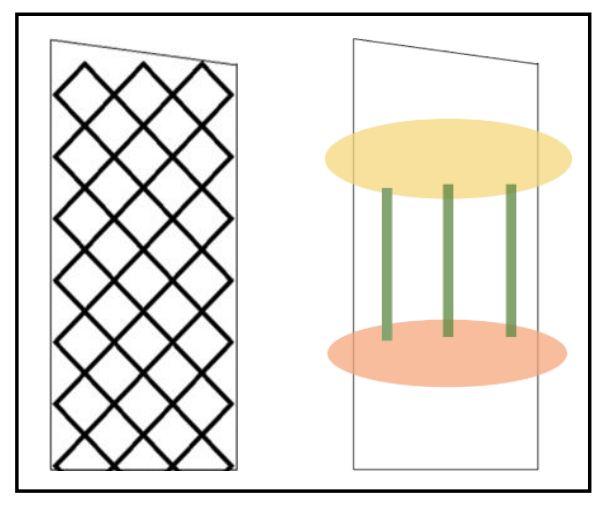

Figure 6 Building mass concept

The Ulos philosophy for the Batak people inspires the building hierarchy concept. Batak people are always given Ulos during their lifetime; birth-life-death [10]. The front segment-birth, visitors will be taken up to the main building and will be shown the whole scenery. Towards the center, the winding road symbolizes life, which brings visitors to the final building where they will be shown a beautiful view at the end of the journey that symbolizes as if they were looking into heaven; death, and each segment has a different elevation (Figure 7). 


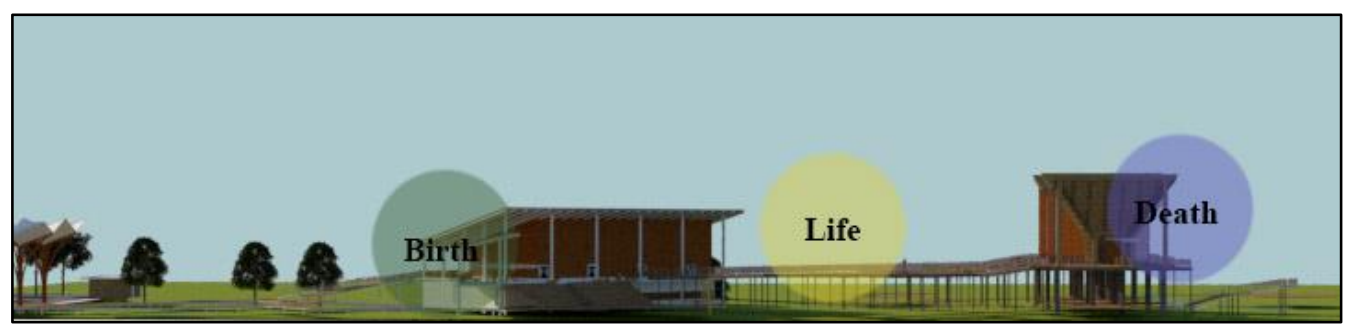

Figure 7 Hierarchy concept

\section{Zoning}

The site is divided into parts: parking area, transition area, main building, connecting bridge, and museum area (Figure 8).

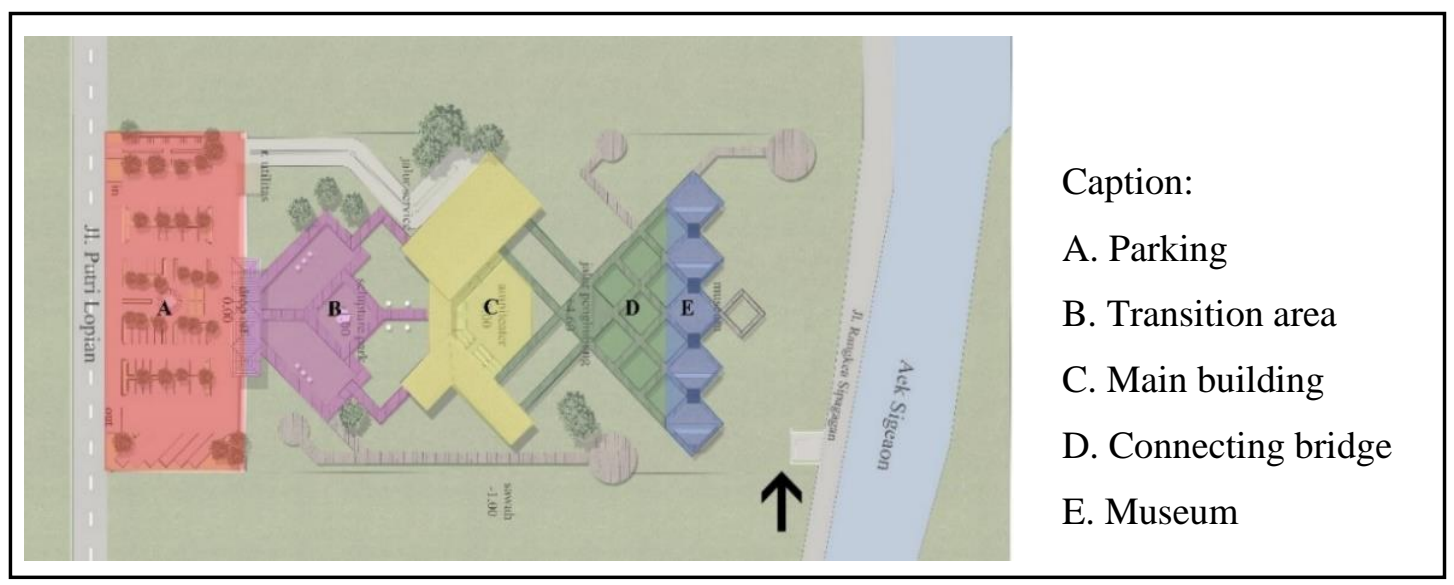

Figure 8 Zoning concept

\section{Circulation}

The site can only be accessed via Jl. Putri Lopian, and exit to the same road. Vehicles can only access the front zone. The building is pushed so that visitors can see the building as a whole from the parking lot (Figure 9).

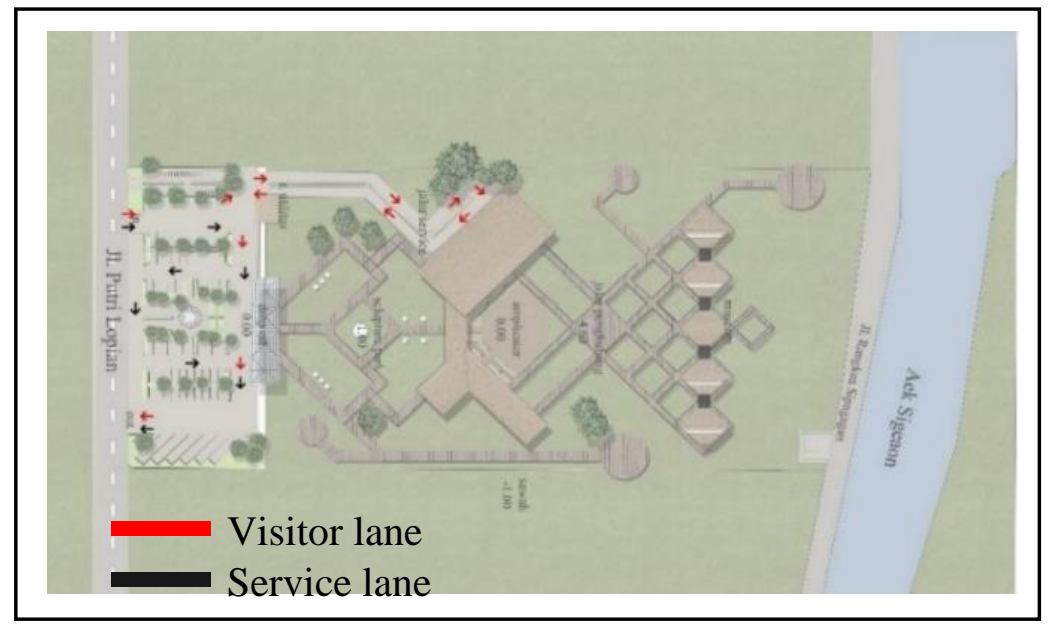

Figure 9 Circulation concept 


\section{Building Mass Concept}

The shape of the building was inspired by the Ulos motifs concept, which was divided into three parts; main building, connecting, and museum building (Figure 10).

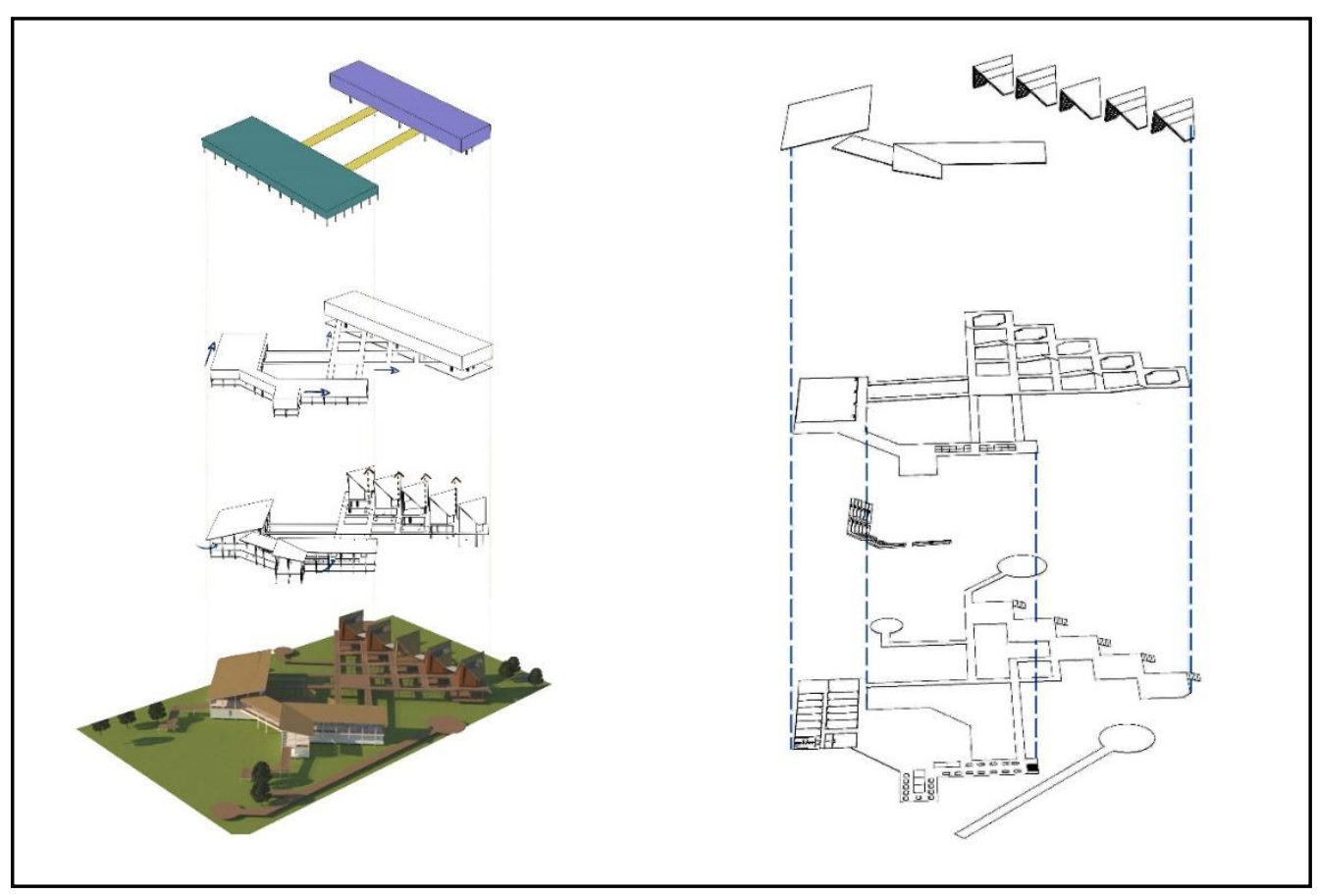

Figure 10 Concept

The building was made thin to allow the rice fields under the building to remain exposed to sunlight. The building was built flowing so that visitors can experience the space and directed from arrival and return (Figure 11).

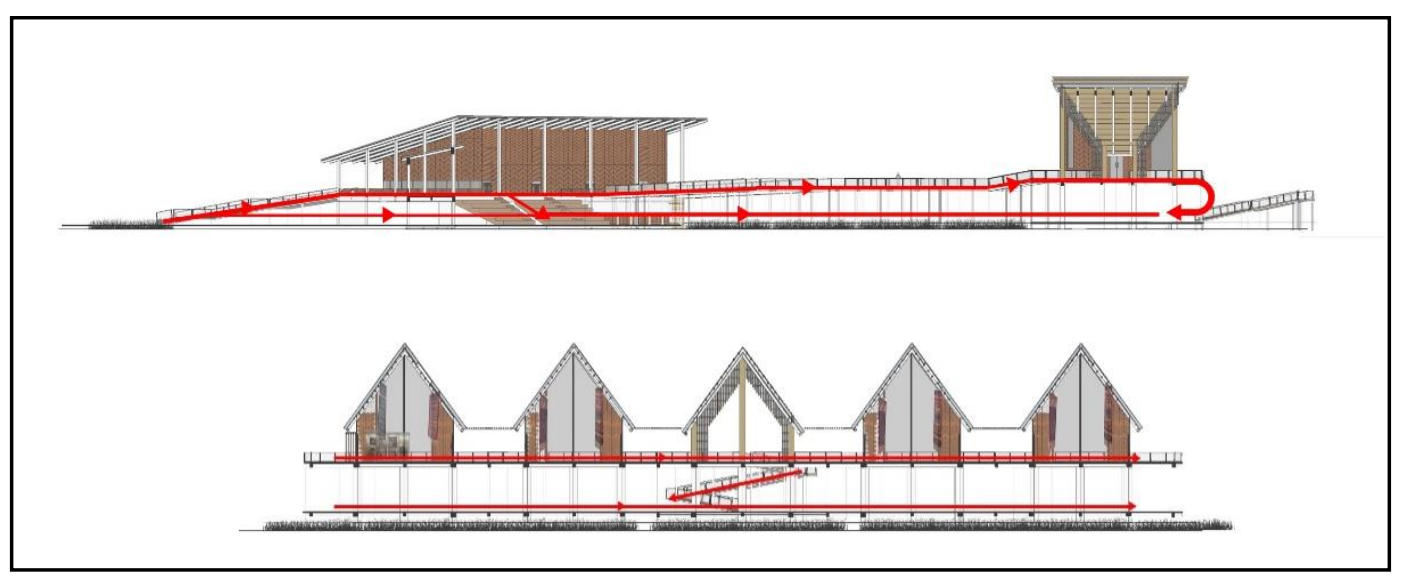

Figure 11 Sequence concept 
The building facade is opened as much as possible, because hills and great views surround the site, and it is allowing air to enter as much as possible. At some spots, platforms were put for visitors to take pictures in a strategic direction (Figure 12).

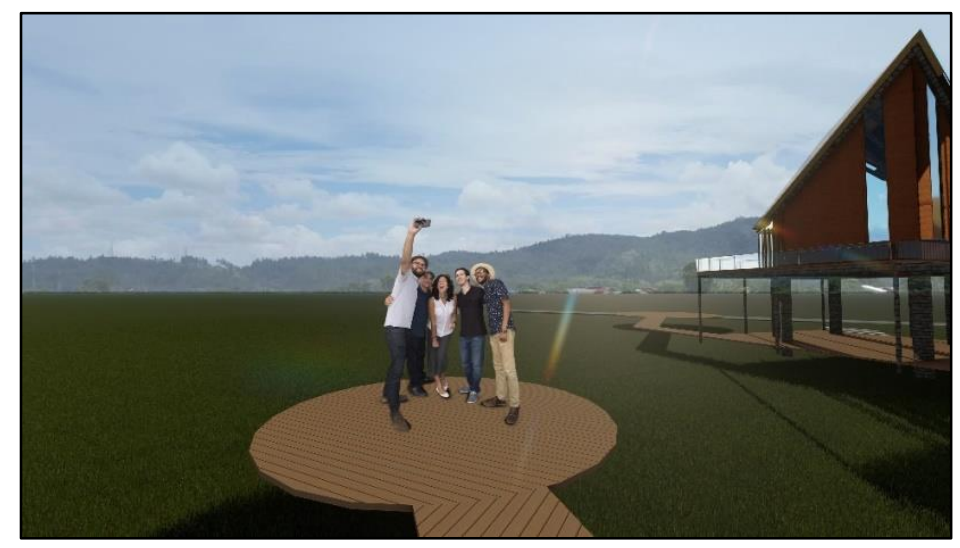

Figure 12 Platform

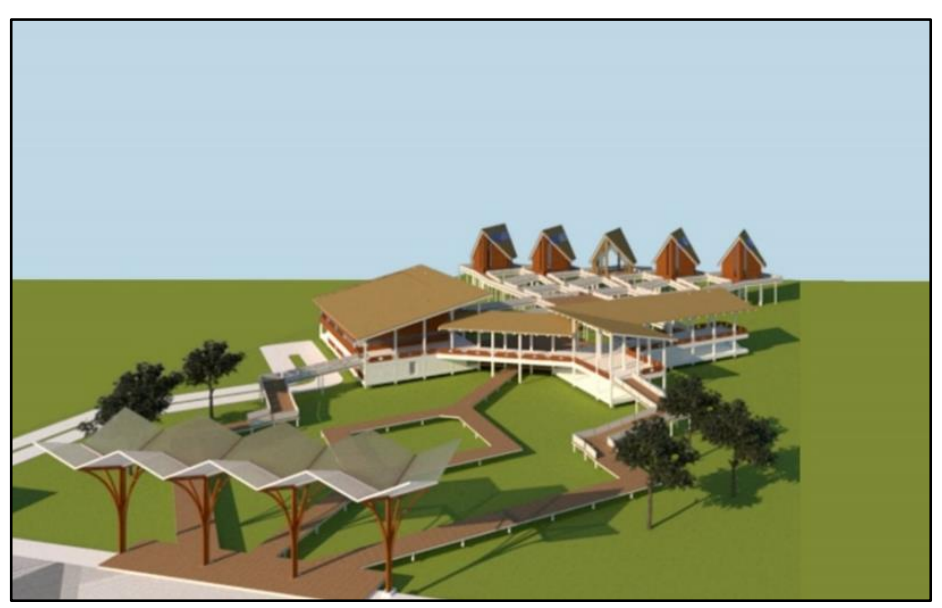

Figure 13 Perspective

The facade is made open as much as possible as if the outside space and inner space had no boundary (Figure 13). Wooden panels are used on the walls to make a natural impression, and openings with glass so that visitors can feel a natural atmosphere even though they are indoors (Figure 14).

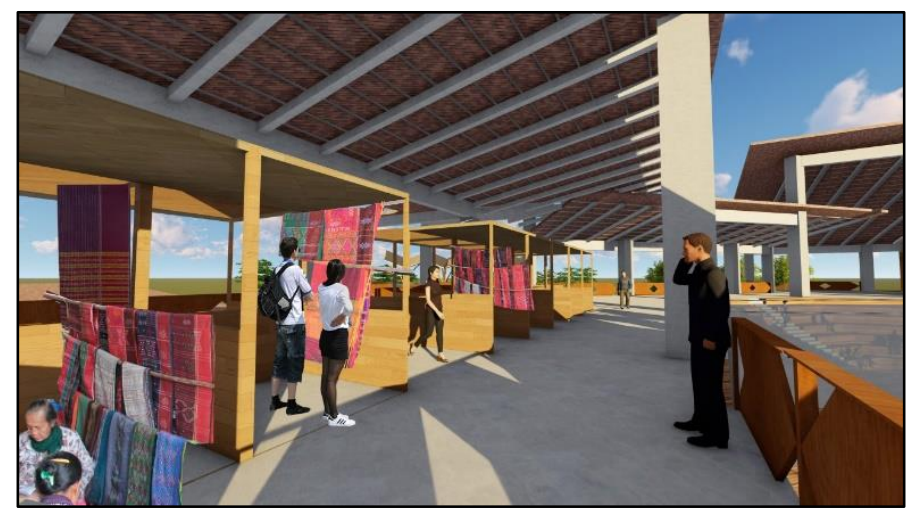

Figure 14 Ulos market 


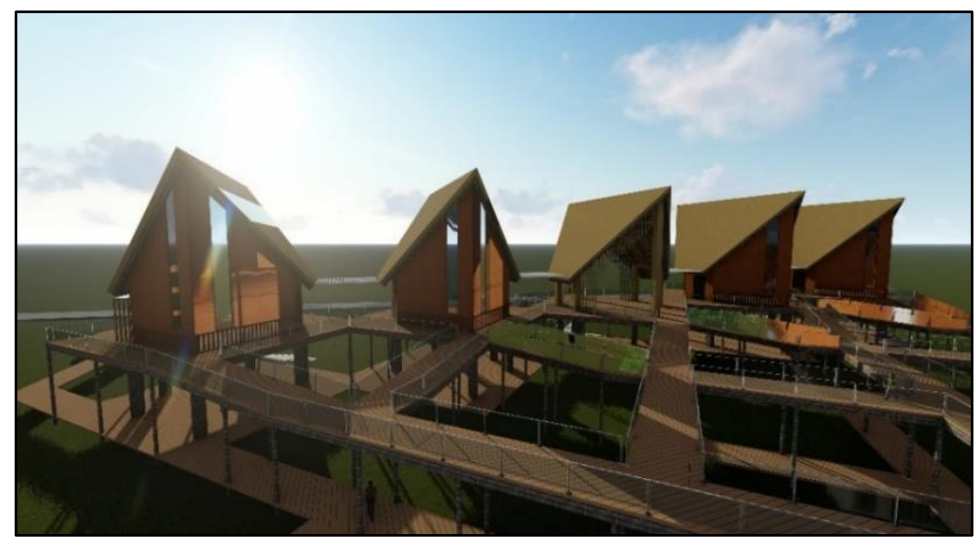

Figure 15 Museum mass concept

\section{Conclusion}

The Ulos Weaving Center in Tarutung is located on Jl. Putri Lopian, Tarutung, North Tapanuli, functioned as a place to collect and exhibit handicrafts from local artists/weavers. It is a place for recreation and education for visitors to get to know Ulos further. Through the Neo Vernacular Architecture theme, the Ulos Weaving Center uses concepts that take into account site conditions and local wisdom, packaged in a modern form.

It is hoped that the Ulos Weaving Center can be used by both local and foreign tourists and will be a place where visitors get a different experience. With the Ulos weaving center's existence, it is hoped that it can empower and boost the economy of local Ulos weavers in Tarutung.

\section{Acknowledgment}

During the research process, the author acknowledged the support of the Architecture Department of the Faculty of Engineering, Universitas Sumatera Utara. This research is a study about Ulos Weaving Center with Neo Vernacular Architecture that intended to give a recommendation to North Sumatera's government about a solution for tourist objects, especially in cultural tourist attractions, to make it a new icon of North Sumatera.

\section{REFERENCES}

[1] Salah Wahab, Tourism Management. London: Tourism International Press, 1975.

[2] Khairunnisa Butar-Butar, "The Aesthetic Study of Traditional Cloth North Sumatera," in International Conference on Business, Economic, Social Science and Humanities, 2018.

[3] Tjok Pradnya Putra. (2014) Pengertian Arsitektur Neo Vernakular. [Online]. https://www.scribd.com/doc/135985062/Pengertian-Arsitektur-Neo-Vernakular

[4] Andi Kumala Sakti, and Hanny Christyne Rumiati Rosaline Tobing, "Physical form sustainability of Huta Siallagan Samosir architecture in supporting Toba Caldera Geopark 
cultural tourism," Jurnal Teknik Arsitektur 5.3, vol. 5, no. 3, 2020.

[5] Aron Samosir, "Transformasi Arsitektur Tradisional Rumah Adat Batak Toba di Toba Samosir," Jurnal Unimed, vol. 6, 2013.

[6] Josef Prijotomo, and Murni Rachmawati. Maria Immaculata Hidayatun, "VERNACULAR ARCHITECTURE AS AN ALTERNATIVE DESIGN APPROACH With Interpretation of Paul Ricoeurs Critical Theory," Petra Christian University, Doctoral dissertation 2016.

[7] Erlyana, "Kajian visual keragaman corak pada kain Ulos," Dimensi DKV, vol. 1, no. 1, April 2016.

[8] MT Siregar, Ulos Dalam Tata Cara Adat Batak. Jakarta Pusat, Indonesia: PT Mufti Harun, 1985.

[9] James Rilatupa, Perkembangan Metode Penelitian Di Bidang Arsitektur (Sebuah Kerangka Pemikiran), 2003.

[10] Syamsul Bahri and Candra Agustina, "Makna dan Fungsi Ulos dalam Adat Masyarakat Batak Toba di Desa Talang Mandi Kecamatan Mandau Kabupaten Bengkalis," Jurnal Online Mahasiswa Fakultas Ilmu Sosial dan Ilmu Politik Universitas Riau, vol. 3, no. 1, February 2016. 